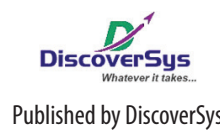

Published by DiscoverSys

\section{Meningkatnya angka kematian ibu (MMRatio): apakah betul?}

\author{
Dewa Nyoman Wirawan ${ }^{1,2^{*}}$
}

${ }^{1}$ Program Studi Magister IImu Kesehatan Masyarakat Universitas Udayana,

${ }^{2}$ Bagian IImu Kedokteran Komunitas dan IImu Kedokteran Pencegahan Fakultas Kedokteran Universitas Udayana

*Korespondensi penulis: Dewa Nyoman Wirawan, Program Studi Magister IImu Kesehatan Masyarakat Universitas Udayana, Bagian IImu Kedokteran Komunitas dan IImu Kedokteran Pencegahan Fakultas Kedokteran Universitas Udayana

wirawandewa48@gmail.com
Dalam Peta Jalan Percepatan Pencapaian Tujuan Pembangunan Mileneum di Indonesia telah ditetapkan bahwa secara nasional Angka Kematian Ibu akibat komplikasi kehamilan dan persalinan per 100.000 kelahiran hidup atau Maternal Mortality Ratio (MMRatio) diharapkan turun dari 228 per 100.000 kelahiran hidup pada tahun 2007 menjadi 102 pada tahun 2015. ${ }^{1}$ Setelah hasil Survei Demografi dan Kesehatan Indonesia (SDKI) tahun 2012 dipublikasikan, banyak pihak amat terkejut karena MMRatio ternyata malah dilaporkan meningkat dari 228 per 100.000 kelahiran hidup pada tahun 2007 (SDKI 2007) ${ }^{2}$ menjadi 359 per 100.000 kelahiran hidup pada tahun 2012 (SDKI 2012). ${ }^{3}$

Keterkejutan banyak pihak dilandasi oleh indikator-indikator ouput upaya pelayanan kesehatan yang ada kaitannya dengan kematian ibu, dimana semuanya menunjukkan peningkatan. Data Riset Kesehatan Dasar (Riskesdas) $2010^{4}$ dan $2013^{5}$ menunjukkan bahwa proporsi wanita kawin yang memakai salah satu metode kontrasepsi pada saat survei (current users) meningkat dari 55,8\% pada tahun 2010 menjadi 59,7\% pada tahun 2013. Cakupan ante natal care (ANC) meningkat dari 92,7\% pada tahun 2010 menjadi $95,2 \%$ pada tahun 2013. Cakupan ANC pertama pada trimester pertama (K1) meningkat dari $72,3 \%$ pada tahun 2010 menjadi 81,3\% pada tahun 2013. Cakupan K4 meningkat dari $61,4 \%$ pada tahun 2010 menjadi $70,0 \%$ pada tahun 2013. Konsumsi tablet Fe selama 90 hari selama hamil meningkat dari $18,0 \%$ tahun 2010 menjadi 33,2\% tahun 2013. Proporsi persalinan oleh tenaga kesehatan meningkat dari $75,4 \%$ pada tahun $2007,{ }^{6} 82,3 \%$ pada tahun 2010 dan $86,9 \%$ pada tahun 2013. Proporsi tempat persalinan di fasilitas kesehatan meningkat dari $60,9 \%$ pada tahun 2010 menjadi $76,1 \%$ pada tahun 2013. Cakupan pelayanan ibu pada masa nifas meningkat dari $46,8 \%$ pada tahun 2010 menjadi 81,7\% pada tahun 2013.

Lalu kenapa angka kematian ibu (MMRatio) malah meningkat? Dalam laporan SDKI 2012 diuraikan bahwa MMRatio yang dijumpai dalam SDKI perlu dicermati dengan amat hati-hati dan seksama. Sumber kesalahan angka yang diperoleh bisa karena sampling error dan nonsampling error. ${ }^{3}$ Kemungkinan sampling error terlihat dari rentangan estimasi MMRatio (95\% confidence interval) yang amat lebar dari hasil SDKI 2012 yaitu 239 per 100.000 kelahiran hidup sampai 478 per 100.000 kelahiran hidup sedangkan rentangan estimasi MMRatio (95\% confidence interval) hasil SDKI 2007 relatif lebih kecil yaitu antara 132-323 per 100.000 kelahiran hidup. ${ }^{3}$ Kemungkinan nonsampling error adalah pertanyaan (kuesioner) yang berbeda, dimana dalam SDKI 2007 jumlah kematian yang ditanyakan hanya pada wanita pernah kawin umur 15-49 tahun saja sedangkan dalam SDKI 2012 ditanyakan untuk semua wanita umur 15-49 tahun baik pernah kawin maupun tidak. ${ }^{3}$ Bila dikaitkan dengan indikator output pelayanan kesehatan seperti diuraikan di atas, cukup besar kemungkinannya bahwa salah satu penyebab meningkatnya MMRatio hasil SDKI 2012 dibandingkan dengan SDKI 2007 adalah karena tambahan kematian wanita umur 15-49 tahun yang tidak pernah kawin.

Dengan demikian, perlu amat hati-hati bila memakai data SDKI tahun 2012 untuk menentukan pencapaian target MDGs di Indonesia. Penelitian lain yang juga mengukur kematian ibu secara nasional adalah Sensus Penduduk 2010 yang sampai saat ini belum dipublikasikan hasilnya. Ada baiknya MMRatio dari hasil Sensus Penduduk 2010 juga dipublikasikan secara transparan disertai ulasan tentang kelemahan-kelemahannya sehingga bisa dikaji oleh berbagai pihak yang pakar di bidangnya.

\section{DAFTAR PUSTAKA}

1. Bappenas (2010). Peta Jalan Percepatan Pencapaian Tujuan Pembangunan Milenium di Indonesia.

2. Statistics Indonesia, National Population and Family Planning Board, Ministry of Health, Macro International (2008). Indonesia Demographic and Health Survey 2007.

3. Statistics Indonesia, National Population and Family Planning Board, Ministry of Health, MEASURE DHS ICF International (2013). Indonesia Demographic and Health Survey 2012.

4. Badan Penelitian dan Pengembangan Kesehatan Departemen Kesehatan RI (2010). Laporan Nasional Riset Kesehatan Dasar (Riskesdas) Tahun 2010.

5. Badan Penelitian dan Pengembangan Kesehatan Departemen Kesehatan RI (2013). Pokok-Pokok Hasil Riskesdas Indonesia 2013.

6. Badan Penelitian dan Pengembangan Kesehatan Departemen Kesehatan RI (2008). Laporan Hasil Riset Kesehatan Dasar (RISKESDAS) Nasional 2007.

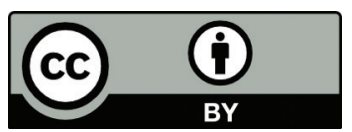

This work is licensed under a Creative Commons Attribution 